\title{
MEASURING THE PROSPECTIVE FOR CAREER DEVELOPMENT IN THE HOSPITALITY INDUSTRY IN NORTH MACEDONIA
}

\author{
Blagica Rizoska Vanikj ${ }^{1}$ \\ Mislim Zendeli ${ }^{2}$
}

Received: April 25, 2019 / Revised: June 10, 2019/ Accepted: September 12, 2019

(C) Association of Economists and Managers of the Balkans, 2019

\begin{abstract}
This research contains eclectic analyses of the theory of human resources development along with the founding's from the empirical research with the main goal to determine the prospects for career development in the hospitality industry in North Macedonia. By using a sample of employees from different gender, age and education, the differences in perception have been evaluated and analyzed. Based on the founding's, the researchers identified the current competencies, the future training needs as well as the career status of the employees in the hospitality industry in North Macedonia. Additionally, the research investigated the differences in the evaluated competencies among different groups of employees (gender, age, education, career status). The measured competencies were divided into six groups: Leadership/Assertiveness, Ethics/Professionalism, Teamwork/Communication, Orientation towards success, Self-management (stress, emotions) and Learning and development. By conducting the set of questionnaires, the quantitative analyses were conducted on the different variables that have been analyzed by computing different statistical methods like descriptive analyses, $t$-test ANOVA and correlation analyses.

The paper also explores the necessity for developing the human resources departments into the organizations from hospitality industry where the educated and experienced professionals will be involved in providing services for competences and career development of each employee based on the organizational and individual needs. This practical approach should increase the awareness of the leaders in the hospitality industry in North Macedonia to invest in the knowledge and development of human resources as the main resource for organizational success and development.
\end{abstract}

Keywords: Hospitality Industry, Career Development, Human Resources Development.

\section{JEL classification $015 \cdot \mathbf{Z 3 2}$}

This paper was presented at the Third International Scientific Conference on Economics and Management - EMAN 2019 - March 28, Ljubljana, Slovenia, www.eman-conference.org

Blagica Rizoska Vanikj

brizoska@gmail.com

University American College, Skopje, North Macedonia

University of Tetovo, Tetovo, North Macedonia 


\section{INTRODUCTION}

The big changes present in everyday life contribute to all segments of human life. In relation to the changes, many different approaches and philosophies are present in the process of managing people and leading business. In today's managerial and business philosophy, the term "capital" is rarely related to money and material tools, on the contrary - it is more related to people, their competences, creativity and development potential (Baum, 1995). In today's business world, only the new knowledge (human capital) and technology can move the bridges of the production capabilities above, and there are the main factors that can increase the production by using the same resources. People, their knowledge, their capabilities, their motivation, and their satisfaction are the main factor for achieving success on both the domestic and the global market (Baum, 1997). The intellectual war for experts, leaders and young talents is a more and more present form of concurrency and, in the same time, leading them is the basic topic in the business literature of the $21^{\text {st }}$ century.

The human resources management (HRM) is constantly changing and developing together with the changes and challenges of modern organizations. The managers of the companies become aware that people with their competences, with their ideas and possibilities, are the most important potential for the organization, the potential that should be led in a rational and human way (International Labour Organization, 2001). The manager-employee relations based on power can be changed with cooperation, teamwork and creative dealing with the set goals by increasing the importance of integrity, initiative and personality of the employees. It is clear that in such conditions, the employees (at any level or function) are not accepting to be employed just to finish their working task and to receive their salary; they want to share their opinions, to present their qualities and to improve themselves as persons by developing their own careers (Kelliher \& Johnson, 1997). As far as the employees recognize the potential for developing their own careers in the organization (no matter the type or size), they work for achieving the organizational goals. The employee that is evaluated, respected and compensated is satisfied with the working status and the work position, and at the same time, he/she is motivated for satisfying their higher needs for career development.

\section{COMPETENCY AND CAREER DEVELOPMENT}

Career development is a natural phenomenon in the professional life of all employees. The most common misconception is that career development automatically means moving up the hierarchical scale in the company. However, career development is a much more complex process, which is mostly conditioned by the following factors: human resources development policy; the company's culture; the experience and performance of each individual and the ability and demonstrated development potential (Millar et al., 2013). In the most companies, employees consider that those who have been employed since the very beginning of the company's work or the longest-serving employees are those who are the most loyal and should be rewarded by giving them the opportunity to further develop their careers. Of course, the career development of these people is not excluded as an option, but what needs to be emphasized is that development is not an exclusive right of "indigenous people" in the company, and development must never be used as a long-term reward in the company (Baum, 1990).

Competence development is a standardized requirement from an individual to perform a particular work activity appropriately. It is a combination of knowledge, rituals, and behavior in favor of better performance. In other words, competence is a condition of an adequate qualification, i.e. having the ability to perform a certain work role (Millar et al., 2013). Competencies 
are usually divided into subgroups, such as analytical thinking, organizational communication, problem-solving, creativity, etc. For example, management competence includes aspects of the thinking system and emotional intelligence as well as negotiation skills and the ability to impose the influence of others (Baum, 1990). A well-developed competency model is a useful tool in the process of strengthening talent management, employment and retention of talents, career planning for employees and managing their performance. The company can also benefit from a good model of competence. The purpose of the model is to outline the required competencies that will guide the behavior towards the most efficient performance of each working category. Knowledge of competencies will also mean helping to identify the most appropriate employee for a particular work role. In the same way, the excellent performance will be differentiated from the average, which will determine the criterion of success (Kelliher \& Johnson, 1997).

Many research studies are trying to identify the crucial competencies in the hospitality industry. Tas (1983), identified the managing guest problems, professionalism and ethics, communication skills and positive attitude towards the other employees and customers as the most important competencies in the hospitality industry (Tesone \& Ricci, 2005). According to Hersey and Blanchard (1988), there are groups of competencies that represent technical, human and conceptual skills as well as demonstration of organization skills, people skills, and leadership. Additionally, Sandwith (1993) presented the five elements competency model that represents the following groups of competences: conceptual-creative, leadership, interpersonal-relational; administrative, regarding personnel and financial management of the business; and technical, concerning the knowledge and skills essential to producing the product or service. Human relation skill (teamwork and relations with others) according to Doyle (1992) are ranked most highly along with elective communication when recruiters make selection decisions for the employees in the hospitality sector.

\section{RESEARCH METHODOLOGY}

In line with the current needs for Human Resources development in the hospitality industry, the researchers developed the practical pilot research for measuring the development of the employee's competencies of 31 participants employed in three restaurants in Tetovo, North Macedonia. By using a sample of employees from different gender (2 groups), age (3 groups) and education (3 groups) the differences in perception for their current career status and their further competence development have been evaluated and analyzed.

The measured competencies were divided in six groups of questions: Leadership/Assertiveness (5 questions), Ethics/Professionalism (3 questions), Teamwork/Communication (12 questions), Orientation towards success (3 questions), Self-management (3 questions) and Learning and development (3 questions). The data for this research has been collected by using the two questionnaires for self-assessment (the competence questionnaire created by the authors and Career status assessment ( 20 questions and three levels: low, middle and high level of career development ${ }^{3}$ ). The questionnaires have been translated and adopted on Macedonian and Albanian language.

\section{RESULTS}

According to the results from the descriptive analyses in general, the participants have a tendency to give high marks on the evaluated groups of competences. As it can be seen on the Table 1 and Chart 1, the mean for all evaluated competences is higher than 4 and it is above the expected mean. However, the crucial needs for competence training according to the employees in the

32006 Career Transitions Unlimited; Dilip Saraf 
restaurant business in North Macedonia are self- management (control of the stress, emotional intelligence), team/communication (dealing with others) and learning and development (constant development of the professional and business knowledge).

Regarding the career development status, the general mean is 3,97 , which represents the middle level of career development in general.

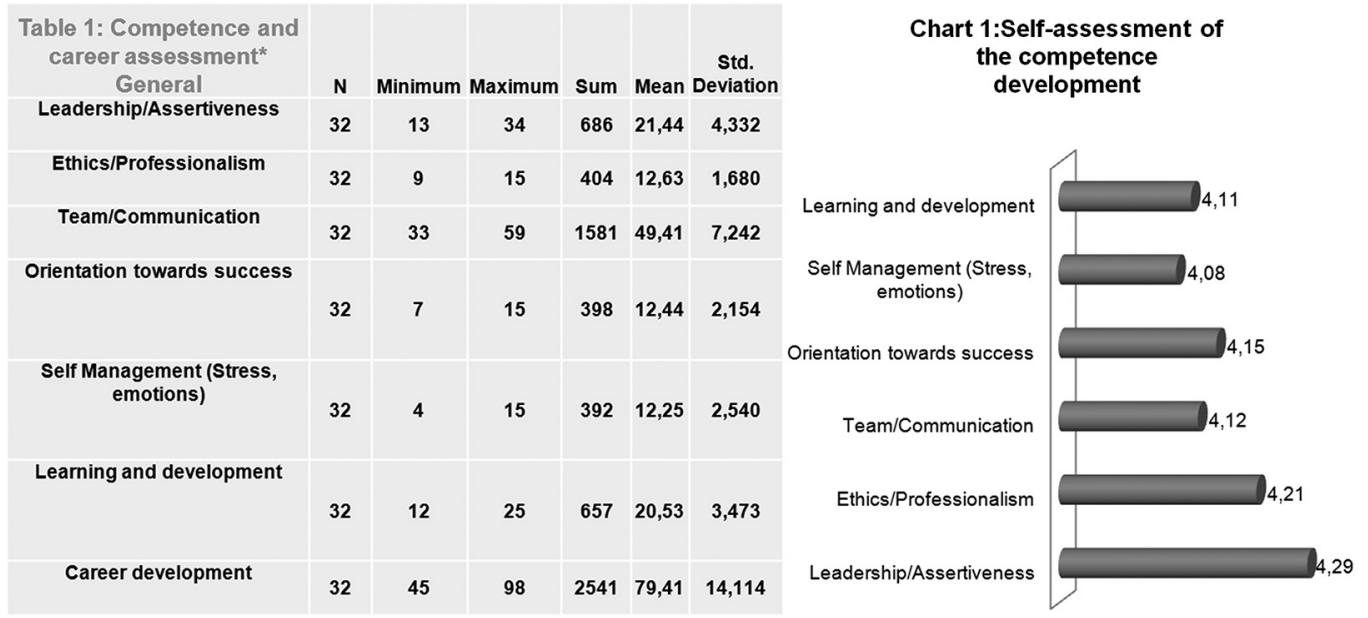

Figure 1. Descriptive statistics-results from the competence and career status assessment

Based on the descriptive statistics and compare means conducted among males and females it can be concluded that females evaluate the level of competences and career development higher than males in all of the measured aspects. However, as it can be seen on the table in figure 3 the difference among males and females is statistically significant for Team/ communication and Career development. This means that the competencies for Teamwork and Communication are significantly higher in the female population compared to the male population. Finally, females average for career development is 94,75 which represents a high level of career development compared with the average of the males $(77,21)$ that represents the middle level.

\begin{tabular}{|c|c|c|c|c|c|}
\hline \multicolumn{2}{|c|}{$\begin{array}{l}\text { Table 2: Competence and } \\
\text { career assessment * Gender }\end{array}$} & $\mathbf{N}$ & Mean & $\begin{array}{l}\text { Std. } \\
\text { Deviation }\end{array}$ & $\begin{array}{l}\text { Std. Error } \\
\text { Mean }\end{array}$ \\
\hline \multirow[t]{2}{*}{ Leadership/Assertiveness } & Female & 4 & 24,50 & 1,000 &, 500 \\
\hline & Male & 28 & 21,00 & 4,456 & 842 \\
\hline \multirow[t]{2}{*}{ Ethics/Professionalism } & Female & 4 & 14,25 & ,500 & ,250 \\
\hline & Male & 28 & 12,39 & 1,663 & ,314 \\
\hline \multirow[t]{2}{*}{ Team/Communication } & Female & 4 & 57,25 & 1,708 & ,854 \\
\hline & Male & 28 & 48,29 & 7,034 & 1,329 \\
\hline \multirow{2}{*}{$\begin{array}{l}\text { Orientation towards } \\
\text { success }\end{array}$} & Female & 4 & 13,75 & ,957 & ,479 \\
\hline & Male & 28 & 12,25 & 2,222 & ,420 \\
\hline \multirow{2}{*}{$\begin{array}{c}\text { Self Management (Stress, } \\
\text { emotions) }\end{array}$} & Female & 4 & 14,25 & ,957 & ,479 \\
\hline & Male & 28 & 11,96 & 2,575 & ,487 \\
\hline \multirow[t]{2}{*}{ Learning and development } & Female & 4 & 24,00 & 2,000 & 1,000 \\
\hline & Male & 28 & 20,04 & 3,372 & 637 \\
\hline \multirow[t]{2}{*}{ Career development } & Female & 4 & 94,75 & 1,893 & ,946 \\
\hline & Male & 28 & 77,21 & 13,728 & 2,594 \\
\hline
\end{tabular}

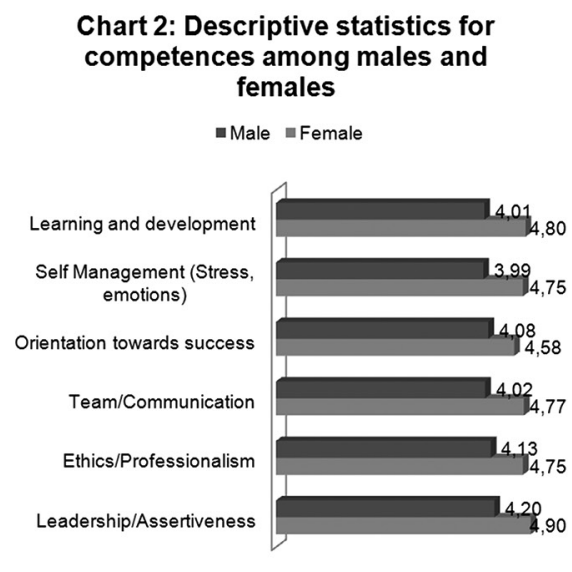

Figure 2. Descriptive statistics-results from the competence and career status assessment for males and females 


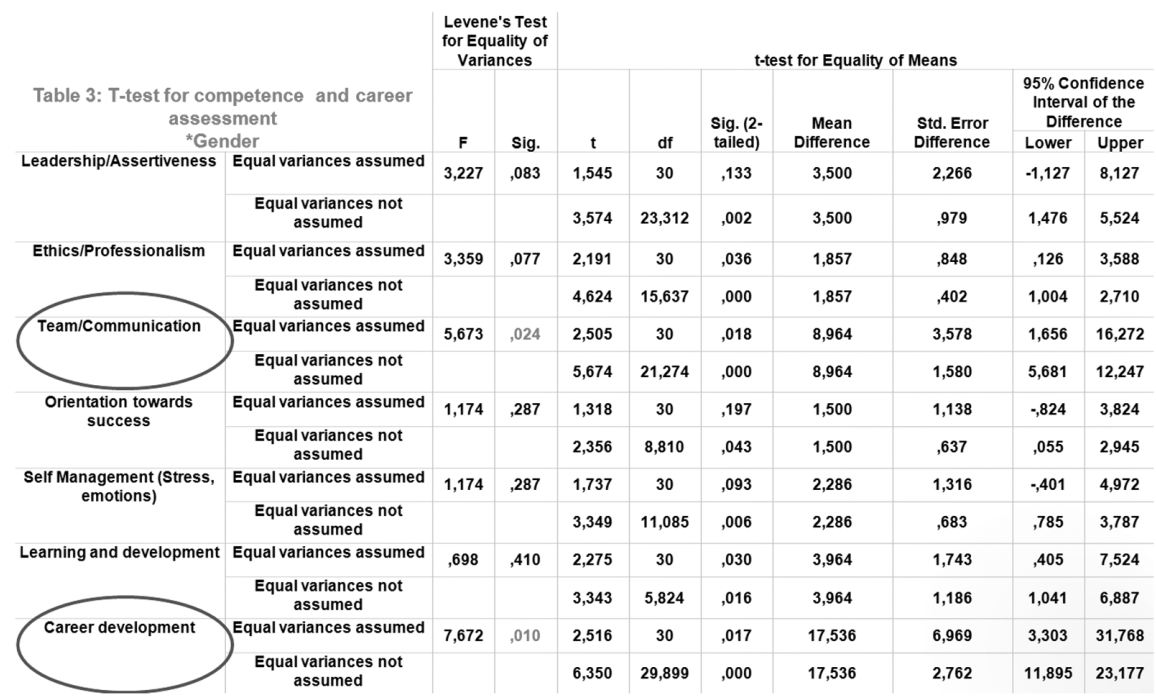

Figure 3. Results for the t-test for competences and career development among males and females
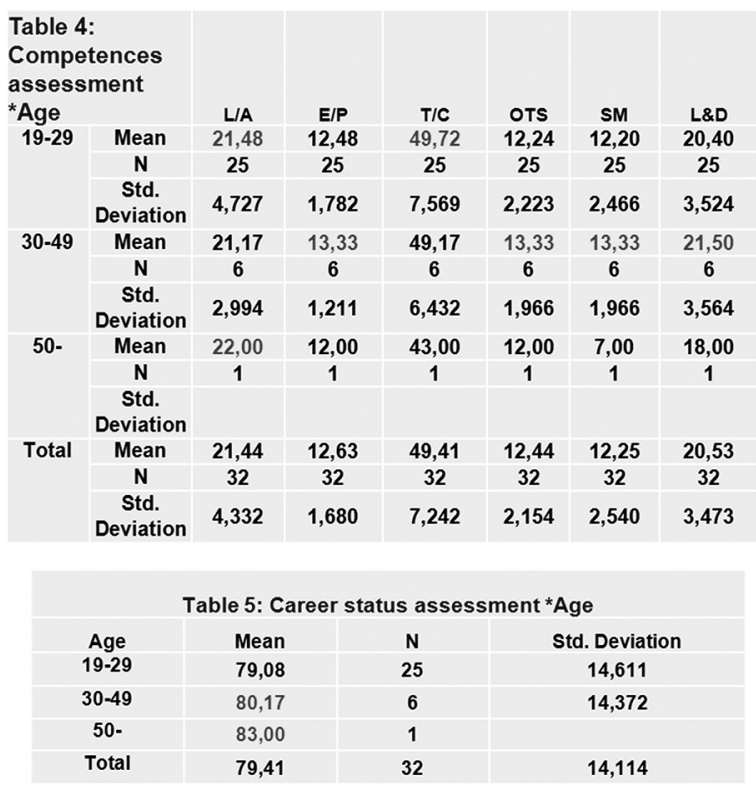

\section{Chart 3: Descriptive statistics for competences among different age groups}

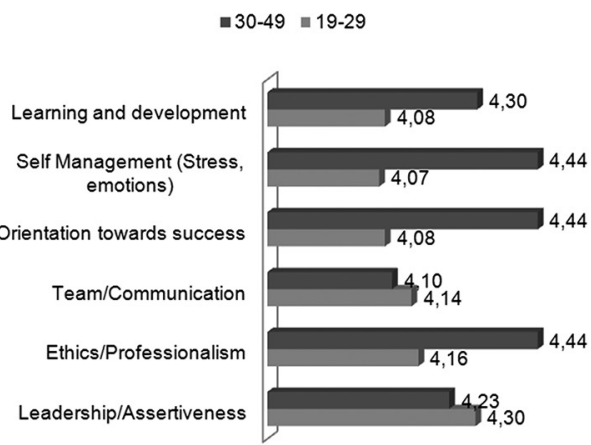

Figure 4. Descriptive statistics-results from the competence and career status assessment for different age groups

Based on the analyses for competence and career assessment among three different age groups it can be concluded that the age group (30-49) has the highest results in competences compared to the others for the most of the evaluated aspects. However, the age group (19-29) has a higher level of competences for Leadership/Assertiveness and Team/Communication. The only statistically significant difference is for Career status assessment/Career development, where the means of the 30-49 group are significantly higher than the means of the group 19-29. The group above 50 years has been excluded from further analyses because of the small number of participants. 


\begin{tabular}{|c|c|c|c|c|c|c|}
\hline \multicolumn{2}{|c|}{$\begin{array}{l}\text { Table 6: ANOVA test for competence and career } \\
\text { assessment *Age }\end{array}$} & $\begin{array}{l}\text { Sum of } \\
\text { Squares }\end{array}$ & df & $\begin{array}{l}\text { Mean } \\
\text { Square }\end{array}$ & $\mathbf{F}$ & Sig. \\
\hline \multirow[t]{3}{*}{ Leadership/Assertiveness } & Between Groups & 88,925 & 2 & 44,463 & 2,616 &, 090 \\
\hline & Within Groups & 492,950 & 29 & 16,998 & & \\
\hline & Total & 581,875 & 31 & & & \\
\hline \multirow[t]{3}{*}{ Ethics/Professionalism } & Between Groups &, 405 & 2 & ,202 & ,067 & ,935 \\
\hline & Within Groups & 87,095 & 29 & 3,003 & & \\
\hline & Total & 87,500 & 31 & & & \\
\hline \multirow[t]{3}{*}{ Team/Communication } & Between Groups & 24,041 & 2 & 12,021 & ,218 & ,806 \\
\hline & Within Groups & 1601,677 & 29 & 55,230 & & \\
\hline & Total & 1625,719 & 31 & & & \\
\hline \multirow[t]{3}{*}{ Orientation towards success } & Between Groups & 7,039 & 2 & 3,519 & ,746 & ,483 \\
\hline & Within Groups & 136,836 & 29 & 4,718 & & \\
\hline & Total & 143,875 & 31 & & & \\
\hline \multirow[t]{3}{*}{ Self Management (Stress, emotions) } & Between Groups & 13,705 & 2 & 6,852 & 1,067 & ,357 \\
\hline & Within Groups & 186,295 & 29 & 6,424 & & \\
\hline & Total & 200,000 & 31 & & & \\
\hline \multirow[t]{6}{*}{ Learning and development } & Between Groups & 61,532 & 2 & 30,766 & 2,856 & ,074 \\
\hline & Within Groups & 312,436 & 29 & 10,774 & & \\
\hline & Total & 373,969 & 31 & & & \\
\hline & Between Groups & 5043,241 & 2 & 2521,621 & 64,573 &, 000 \\
\hline & Within Groups & 1132,477 & 29 & 39,051 & & \\
\hline & Total & 6175,719 & 31 & & & \\
\hline
\end{tabular}

Figure 5. ANOVA test for competences and career development among different age groups

\begin{tabular}{|c|c|c|c|c|c|c|c|}
\hline \multicolumn{2}{|c|}{$\begin{array}{l}\text { Table 7: Competence } \\
\text { assessment }{ }^{\star} \text { Education }\end{array}$} & \multirow{2}{*}{$\begin{array}{c}\text { LAA } \\
20,83\end{array}$} & $E / P$ & & \multirow{2}{*}{$\begin{array}{l}\text { OTS } \\
11.50\end{array}$} & \multirow{2}{*}{$\frac{S M}{12,33}$} & \multirow{2}{*}{$\begin{array}{l}\text { L\&D } \\
20,17\end{array}$} \\
\hline \multirow[t]{3}{*}{ High school } & Mean & & 12,33 & 46,67 & & & \\
\hline & $\mathrm{N}$ & 6 & 6 & 6 & 6 & 6 & 6 \\
\hline & $\begin{array}{l}\text { Std. } \\
\text { Deviation }\end{array}$ & 2,483 & 2,160 & 9,266 & 2,345 & 1,506 & 983 \\
\hline \multirow[t]{3}{*}{ Faculty } & Mean & 21,65 & 12,78 & 50,39 & 12,70 & 12,70 & 21,09 \\
\hline & $\mathrm{N}$ & 23 & 23 & 23 & 23 & 23 & 23 \\
\hline & $\begin{array}{l}\text { Std. } \\
\text { Deviation }\end{array}$ & 4,867 & 1,650 & 6,423 & 2,098 & 2,530 & 3,825 \\
\hline \multirow{3}{*}{$\begin{array}{l}\text { Master and Doctorate } \\
\text { degree }\end{array}$} & Mean & 21,00 & 12,00 & 47,33 & 12,33 & 8,67 & 17,00 \\
\hline & $\mathrm{N}$ & 3 & 3 & 3 & 3 & 3 & 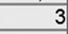 \\
\hline & $\begin{array}{l}\text { Std. } \\
\text { Deviation }\end{array}$ & 3,606 & 1,000 & 10,214 & 2,517 & 1,528 & 1,000 \\
\hline \multirow[t]{3}{*}{ Total } & Mean & 21,44 & 12,63 & 49,41 & 12,44 & 12,25 & 20,53 \\
\hline & $\mathrm{N}$ & 32 & 32 & 32 & 32 & 32 & 32 \\
\hline & $\begin{array}{l}\text { Std. } \\
\text { Deviation }\end{array}$ & 4,332 & 1,680 & 7,242 & 2,154 & 2,540 & 3,473 \\
\hline
\end{tabular}

Table 8: Career status assessment * Education

\begin{tabular}{|c|c|c|c|}
\hline Education & Mean & N & Std. Deviation \\
\hline High school & 77,50 & 6 & 9,182 \\
\hline $\begin{array}{c}\text { Faculty } \\
\text { Master and }\end{array}$ & 79,91 & 23 & 15,500 \\
\hline Doctorate degree & 79,33 & 3 & 14,844 \\
\hline Total & 79,41 & 32 & 14,114 \\
\hline
\end{tabular}

Chart 4: Descriptive statistic for competence among different education group

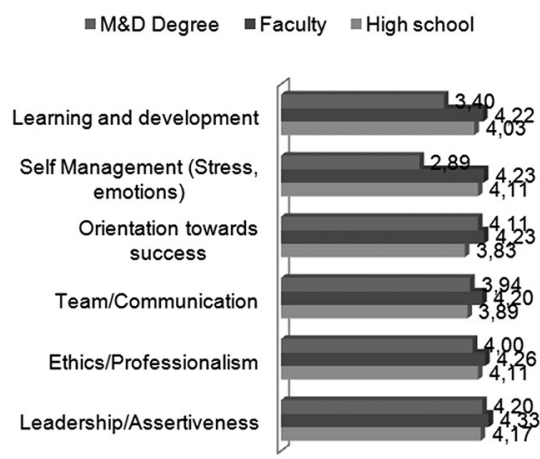

Figure 6. Descriptive statistics-results from the competence and career status assessment for different educational groups

According to the results of competence and career status assessment among three groups of participants based on their level of education, as presented in Figure 7, it can be concluded that the education group of employees that have finished faculty has the highest scores in all of the measured competencies as well as the level of career development. Additionally, the difference between the three educational groups is significant only for the competencies for Self- management (stress-emotions). 


\begin{tabular}{|c|c|c|c|c|c|c|}
\hline \multirow{2}{*}{\multicolumn{2}{|c|}{$\begin{array}{l}\text { Table 9: Anova test for competences and } \\
\text { career development*Education } \\
\text { Leadership/Assertiveness Between Groups }\end{array}$}} & \multirow{2}{*}{$\begin{array}{c}\text { Sum of } \\
\text { Squares } \\
3,824\end{array}$} & \multirow{2}{*}{$\begin{array}{c}\text { df } \\
2\end{array}$} & \multirow{2}{*}{$\begin{array}{c}\text { Mean Square } \\
1,912\end{array}$} & \multirow{2}{*}{$\begin{array}{c}\mathbf{F} \\
, 096\end{array}$} & \multirow{2}{*}{$\begin{array}{l}\text { Sig } \\
\text {,909 }\end{array}$} \\
\hline & & & & & & \\
\hline & Within Groups & 578,051 & 29 & 19,933 & & \\
\hline & Total & 581,875 & 31 & & & \\
\hline \multirow[t]{3}{*}{ Ethics/Professionalism } & Between Groups & 2,254 & 2 & 1,127 & ,383 &, 685 \\
\hline & Within Groups & 85,246 & 29 & 2,940 & & \\
\hline & Total & 87,500 & 31 & & & \\
\hline \multirow[t]{3}{*}{ Team/Communication } & Between Groups & 80,240 & 2 & 40,120 &, 753 & ,480 \\
\hline & Within Groups & 1545,478 & 29 & 53,292 & & \\
\hline & Total & 1625,719 & 31 & & & \\
\hline \multirow[t]{6}{*}{ Orientation towards success } & Between Groups & 6,839 & 2 & 3,419 & ,724 & ,494 \\
\hline & Within Groups & 137,036 & 29 & 4,725 & & \\
\hline & Total & 143,875 & 31 & & & \\
\hline & Between Groups & 43,130 & 2 & 21,565 & 3,987 &, 030 \\
\hline & Within Groups & 156,870 & 29 & 5,409 & & \\
\hline & Total & 200,000 & 31 & & & \\
\hline \multirow[t]{3}{*}{ Learning and development } & Between Groups & 45,309 & 2 & 22,655 & 1,999 & ,154 \\
\hline & Within Groups & 328,659 & 29 & 11,333 & & \\
\hline & Total & 373,969 & 31 & & & \\
\hline \multirow[t]{3}{*}{ Career development } & Between Groups & 27,726 & 2 & 13,863 &, 065 & ,937 \\
\hline & Within Groups & 6147,993 & 29 & 212,000 & & \\
\hline & Total & 6175,719 & 31 & & & \\
\hline
\end{tabular}

Figure 7. Anova test for competences and career development among different education groups

\begin{tabular}{|c|c|c|c|c|c|c|c|}
\hline \multirow{3}{*}{$\begin{array}{l}\text { development } \\
\text { Leadership/Assertiveness }\end{array}$} & L/A & $E / P$ & $T / C$ & OTS & SM & L\&D & Career development \\
\hline & 1 & 289 &, $557^{\prime \prime}$ & $387^{*}$ & ,236 &, $383^{\star}$ &, $529^{n-}$ \\
\hline & & 108 & ,001 & ,029 & 194 & 031 & 002 \\
\hline \multirow{4}{*}{ Ethics/Professionalism } & 32 & 32 & 32 & 32 & 32 & 32 & 32 \\
\hline & ,289 & 1 &, $530^{*}$ &, $368^{*}$ &, 280 &, $411^{*}$ & ,224 \\
\hline & 108 & & ,002 & ,038 & ,121 & 019 & 217 \\
\hline & 32 & 32 & 32 & 32 & 32 & 32 & 32 \\
\hline \multirow[t]{3}{*}{ Team/Communication } &, $557^{*}$ &, $530^{*+}$ & 1 &, $615^{* *}$ &, 320 &, $387^{*}$ & ,345 \\
\hline & ,001 & ,002 & &, 000 & ,074 & ,028 & 053 \\
\hline & 32 & 32 & 32 & 32 & 32 & 32 & 32 \\
\hline \multirow[t]{3}{*}{ Orientation towards success } &, $387^{*}$ &, $368^{*}$ &, $615^{\text {"*x }}$ & 1 &, $545^{* \prime \prime}$ &, $623^{\mathrm{m}}$ &, $358^{*}$ \\
\hline &, 029 & ,038 &, 000 & & ,001 & ,000 & 044 \\
\hline & 32 & 32 & 32 & 32 & 32 & 32 & 32 \\
\hline \multirow{3}{*}{$\begin{array}{c}\text { Self Management (Stress, } \\
\text { emotions) }\end{array}$} & ,236 & ,280 & ,320 &, $545^{\circ *}$ & 1 & $829^{m-}$ & 345 \\
\hline & 194 & 121 & ,074 & ,001 & & ,000 & ,053 \\
\hline & 32 & 32 & 32 & 32 & 32 & 32 & 32 \\
\hline \multirow[t]{3}{*}{ Learning and development } & $383^{\star}$ & ,411^ & $387^{\star}$ &, $623^{\mu \prime}$ & $829^{\prime \prime}$ & 1 &, $569^{m}$ \\
\hline & 031 & ,019 & ,028 & ,000 & ,000 & & ,001 \\
\hline & 32 & 32 & 32 & 32 & 32 & 32 & 32 \\
\hline \multirow[t]{3}{*}{ Career development } &, $529^{*}$ & ,224 & ,345 &, $358^{*}$ & ,345 &, $569^{\text {* }}$ & 1 \\
\hline & ,002 & ,217 & ,053 & ,044 & ,053 & ,001 & \\
\hline & 32 & 32 & 32 & 32 & 32 & 32 & 32 \\
\hline
\end{tabular}

Figure 8. Correlation analyses of the competence and career development (Pearson Sig.2-N)

Finally, based on the founding's from the correlation analyses, the relation between the different groups of competencies and career development is significant for the Leadership/Assertiveness, Orientation towards success and Learning and development. This means that the level of development of the leadership/assertiveness skills, orientation towards successes and willingness for continuous development will develop is in line with the career development. 


\section{CONCLUSION}

All resources of production are important, like machines, capital, money, land, etc. in order to ensure the achievement of production of a running factory. Overall supremacy has to be given to the element of human resources. Man, itself, ensures the economical use of resources by applying wisdom. Hence, any amount of efforts spent on training of human resources will yield its appropriate result and higher productivity for the organization. The prospects and growth, productivity and profitability of an organization depend on effective utilization of such resources, employed in the effort of achieving company objectives. The achievement of an organization can be seen as a result of cooperation and hard work at all the levels of functioning of an organization. Any huge capital investment in developing the infrastructure of a training institute and its running will show results in achieving higher productivity and profitability in the years that come.

The paper gives a clearer picture for the most important competencies for career development in the restaurant businesses in North Macedonia. It represents that there is a need of integrated use of training and development, career development, and organization development in order to improve employee's individual effectiveness.

The professionals for human resources management as well as the managers of the organization in the hospitality industry in North Macedonia should create the set of systematic and planned activities designed to provide its members with the opportunities to learn necessary skills to meet current and future job demands. This process should begin when an employee joins an organization and continue throughout his or her career, regardless of whether that employee is an executive or a worker on an assembly line. The human resources development programs must respond to job changes and integrate the long-term plans and strategies of the organization to ensure the efficient and effective use of resources.

\section{REFERENCES}

Baum, T. (1990). "Competencies for Hotel Management: Industry Expectations of Education", International Journal of Contemporary Hospitality Management, Vol. 2 Issue: 4

Baum, T. (1995). Managing Human Resources in the European Hospitality and Tourism Industry - A Strategic Approach, Chapman and Hall.

Baum, T. (1997). Making or breaking the tourist experience: the role of human resource management', in C. Ryan (ed.) The Tourist Experience: A New Introduction, Cassell, 92-111.

Doyle, K. O. (1992). Introduction: Money and the Behavioral Sciences. American Behavioral Scientist, 35, 641-657.

Hersey, P., \& Blanchard, K. H. (1988). Management and Organizational Behavior. Englewood Cliffs, NJ: Prentice-Hall.

International Labour Organization. (2001). Human Resource Development, Employment and Globalization in the Hotel Catering and Tourism Sector, ILO

Kelliher, C. \& Johnson, K. (1997). "Personnel management in hotels - an update: a move to human resource management?", Progress in Tourism and Hospitality Research, 3, 321-331.

Millar, M. \& Mao, Z. \& Moreo, P. (2013). Hospitality \& Tourism Educators vs. The Industry: A Competency Assessment. Journal of Hospitality \& Tourism Education. 22.

Sandwith, P. (1993). A hierarchy of management training requirements: The competency domain model. Public Personnel Management, 22, 43-63.

Tesone, V. D. \& Ricci, P. (2005). Job Competency Expectations for Hospitality and Tourism Employees. Journal of Human Resources in Hospitality \& Tourism. 4. 